2019 TheoLogica

An International Journal for Philosophy of Religion and Philosophical Theology

S. I. GOD'S NATURE AND ATTRIBUTES

DOI: https://doi.org/10.14428/thl.v3i2.52523

\title{
Editorial: God's Nature and Attributes
}

\author{
IDE LÉVI
}

École Pratique des Hautes Études

ide.esmire.levi@gmail.com

\section{ALEJANDRO PÉREZ \\ Catholic University of Louvain \\ alejotou@gmail.com}

In Western theism, different attributes have classically been ascribed to God, such as omnipotence, omniscience, wisdom, goodness, freedom and so on. But these ascriptions have also raised many conceptual difficulties: are these attributes internally coherent? Are they really compossible? Are they compatible with what we know about the world (e.g. the existence of evil, human freedom, the laws of nature etc.). These traditional questions are part of the inquiry on God's nature as it is carried out in contemporary philosophy of religion. Another part of this inquiry is constituted by theological and philosophical questions raised by more precise or particular religious conceptions of God - e.g. the doctrine of Trinity in Christianity, or other specific credentials about the right way to understand God's perfection and absolute transcendence in Judaism, Christianity or Islam.

In this issue, we propose to follow these two directions of the inquiry about God's nature and attributes through historical and systematic studies, in the perspective of contemporary philosophy of religion and analytical theology. While the three papers specifically dedicated to the problem of the Trinity pertain mainly to the second part of the examination (the conceptual analysis of specific credentials and theological doctrines), the three others offer new perspectives and arguments on traditional questions about God, like the problem of evil, perfect goodness, or the problem of divine perfection and God's freedom.

The issue begins with two historical (and systematic) papers on the topic, which contribute also to the contemporary renewal of Anselmian studies. In the first one, Jeffrey E. Brower deals with the opening chapter of the Monologion, where Anselm offers a proof for the existence of a Platonic form of goodness, which constitutes an important step in his argument for God's existence. Through this precise analysis of the proof, Brower invites us to revisit Anselm's theory of universals and his metaphysics of goodness and to consider the philosophical interest of Anselm's argument for Platonism about goodness as it deserves. In the second historical paper, Christopher Hughes Conn analyses Anselm's response to Roscelin of Compiègne's theory about Trinity and 
especially to Roscelin's claim that there is a substantial distinction between the Father and the Son. Conn argues that Anselm's response to Roscelin constitutes an account of the Triune God based on a strongly relativised conception of identity. Anselm, as Conn puts it, may have been the first Christian philosopher to establish that the doctrine of the consubstantial Trinity is incompatible with the principle of indiscernibility, and was the first to discover that the doctrine of the Holy Trinity is logically committed to relative identity.

In the third paper, William Hasker enquires about the one divine nature of God, through an investigation of different trinitarian models. In this essay, Hasker offers a metaphysical account of the doctrine of the Trinity in terms of the theory of material constitution and defends a social and constitutionalist conception of the Trinity, while insisting on the existence of a single concrete divine nature. On the same subject, Ryan Byerly's paper provides research about recent developments in the theory of truthmaker in order to respond to the philosophical challenge issued by the Christian doctrine of the Trinity. Thus, according to Byerly's Truthmaker Trinitarianism, each one of Father, Son, and Spirit serves as the only substantial constituent of equally minimal truthmakers for claims about God.

Ide Lévi discusses Brian Leftow's voluntarist account of divine choice and proposes several ways to understand the claim that God does not necessarily choose the best. In her paper, Lévi defends a form of 'voluntarist optimalism' about divine choice, which constitutes an attempt to preserve the gratuitous character of God's love and choices without refusing the principle of the best. In the last paper, Graham Floyd studies the principle of organic unities (according to which the value of the whole is not equal to the summation of its parts) in relation to the problem of God and evil, and seeks to demonstrate that God may logically co-exist with evil. We expect that the reader will appreciate this renewal of classic problems.

Some of these papers were presented in the Analytic Theology Cluster at Paris led by Frédéric Nef and Alejandro Pérez at Institut Jean Nicod, a project funded by the University of Innsbruck and the John Templeton Foundation. We are very grateful to the participants (Paul Clavier, Jean-Baptiste Guillon, Lydia Jaeger, Ide Lévi, Cyrille Michon, and Yann Schmitt), as well as to Georg Gasser for his support. 